\title{
KEARIFAN LOKAL TRI HITA KARANA DALAM PROGRAM CORPORATE SOCIAL RESPONSIBILITY
}

\author{
Yeni Rosilawati, Krisna Mulawarman \\ Program Studi Ilmu Komunikasi Universitas Muhammadiyah Yogyakarta (UMY), Jalan \\ Brawijaya, Kasihan, Geblagan, Tamantirto, Kasihan, Bantul \\ Email: yenirosilawati@gmail.com; Telp: +6281904907606
}

\begin{abstract}
Extant research has confirmed that influence of local factors (social, cultural, political and economic) on the implementation of CSR across worldwide. The rise of conflict between firms and communities emphasizes the understanding of socio-cultural aspects in the context of communities. This study aimed to explore the effects of Tri Hita Karana local wisdom on the CSR initiatives through a case study in Aqua Danone, Bali. This study has employed a qualitative paradigm where in-depth interviews were conducted with local community members, local community leaders, NGO employees, and managers who are involved with CSR initiatives and strategies on daily basis. Secondary data such reports about CSR programs were also employed in this study. The finding shows that local wisdom of Tri Hita Karana (THK) that integrated worship, man and nature has been adopted as a CSR guidance and appears across all levels of CSR starting from the program planning phase and going through the preparation of strategies until the process of implementation and control. This study also concluded that CSR program should consider local forums such as sangkep (routine meeting held by the village) and the enforcement of local rules (pararem) to engage the local communities to run it sustainably. This research recommends the application of local wisdom relevant to CSR implementation
\end{abstract}

Keywords: Local Wisdom, Tri Hita Karana, Corporate Social Responsibility, Communities, Local

\begin{abstract}
ABSTRAK
Faktor-faktor lokal seperti sosial budaya, politik serta ekonomi mempengaruhi pelaksanaan CSR di berbagai negara. Konflik yang seringkali terjadi antara perusahaan dan masyarakat lokal menunjukkan bahwa perusahaan perlu memahami sosial budaya masyarakat dan etika setempat sebelum beroperasi. Penelitian ini bertujuan untuk mengevaluasi program CSR dalam menerapkan kearifan lokal Tri Hita Karana (THK) dengan mengambil studi kasus di Aqua Danone Bali. Penelitian ini menggunakan paradigma kualitatif sedangkan cara pengumpulan datanya menggunakan teknik tanya jawab dengan warga setempat, pemimpin masyarakat lokal, anggota LSM mitra dan manager CSR serta koordinator CSR yang bertanggung jawab dengan program CSR secara langsung. Data sekunder diperoleh melalui website, laporan CSR perusahaan dan berita-berita di media massa mengenai CSR Aqua Danone Bali. Dari hasil penelitian diperoleh bahwa kearifan lokal Tri Hita Karana (THK) yaitu mengintegrasikan elemen peribadatan, manusia dan alam digunakan sebagai panduan program CSR dan digunakan setiap tahap CSR mulai dari perencanaan, strategi pelaksanaan hingga evaluasi CSR. Penelitian juga menyimpulkan program CSR dilaksanakan melalui sumber-sumber lokal yang tersedia dalam masyarakat setempat seperti forum-forum lokal seperti sangkep (rapat rutin) di desa serta menggunakan aturan adat (pararem) untuk melibatkan masyarakat setempat dalam melaksanakan program CSR secara berkelanjutan. Penelitian ini merekomendasikan kebijakan bagi perusahaan yang akan menerapkan program CSR perlu mempertimbangkan kearifan lokal yang hidup dalam masyarakat.
\end{abstract}

Kata kunci: Kearifan Lokal, Tri Hita Karana, Corporate Social Responsibility, masyarakat, lokal

\section{Pendahuluan}

Corporate Social Responsibility (CSR) menjadi isu yang semakin penting di dunia bisnis dan mendapat perhatian dari kalangan akademisi (Petkeviciene, 2015: 503). CSR menjadi perbincangan pada medio abad XX. Saat itu dunia mengalami sejumlah bencana industri. Contohnya, kebocoran 
gas dari perusahaan bernama Union Carbide (di Bhopal, India, pada 1984). Ada pula peristiwa minyak yang ditumpahkan perusahaan British Petroleum (di Teluk Meksiko pada 2010), skandal korporat Enron pada 2001, dan WorldCom pada tahun 2002, kebangkrutan dan kegagalan korporat (Lehman Brother, Merrill Lynch dan Bear Stearns tahun 2008). Pada dasarnya, CSR berhubungan dengan perilaku korporat dan perilaku tanggung jawab yang melebihi kewajiban hukum dan legal (Sun, Stewart dan Pollard, 2010: 5)

Tuntutan untuk melakukan bisnis yang beretika dan transparan menjadi salah satu tantangan perusahaan dan pelaku usaha pada saat ini. Perusahaan dan pelaku bisnis diharapkan berbuat lebih dalam membantu menyelesaikan persoalan-persoalan yang dihadapi oleh dunia seperti perubahan iklim, kemiskinan dan kesehatan. Berdasarkan survei yang dilakukan oleh McKinsey menunjukkan bahwa 95\% CEO di dunia percaya bahwa masyarakat menaruh harapan besar terhadap tanggung jawab sosial yang dilakukan perusahaan. (Frynas, 2009: 179).

CSR juga memiliki arti penting di era masyarakat konsumen. Konsumen semakin sadar terhadap aspek-aspek sosial dari produk dan perusahaan (Shah \& Chen, 2010: 137). Lo dan Sheu (2007: 345) menambahkan bahwa tindakan yang tidak beretika yang dilakukan oleh perusahaan terhadap stakeholders mempengaruhi potensi keuntungan perusahaan yang akan didapatkan di masa depan.

CSR dipengaruhi isu-isu lokal yang berkembang, tradisi-tradisi yang hidup di masyarakat serta budaya masyarakat, serta sejarah masing-masing negara (Chapple \& Moon, 2005; Cruz \& Boehe, 2010; Godiwalla, 2012). Sedangkan Argandona dan Hoivik (2009) mengatakan bahwa konsep CSR berubah dari waktu ke waktu serta dipengaruhi faktor-faktor budaya, politik, sosial, ekonomi, sejarah, serta keadaan negara masing-masing. Penelitian ini bertujuan mengevaluasi program CSR dalam menerapkan kearifan lokal Tri Hita Karana (THK) dengan mengambil studi kasus dalam Program WASH (Water Access Hygiene and Sanitation) yang dilaksanakan oleh Aqua Danone Bali, di wilayah Desa Plaga, Kabupaten Badung.

Konsep CSR dipengaruhi pemikiran bahwa keberadaan perusahaan bergantung hidup dari lingkungan dan masyarakat dimana dia berada. MenurutDaft(2016) CSR adalah kewajiban perusahaan berkontribusi kontribusi untuk kesejahteraan masyarakat dan organisasi itu sendiri. Sedangkan definisi CSR menurut World Business Council for Sustainable Development (Micheal, 2003), CSR merupakan kontribusi terhadap pembangunan ekonomi, bekerjasama dengan pegawai maupun pekerja, keluarga pekerja atau pegawai perusahaan, masyarakat lokal dan masyarakat secara umum dalam usaha untuk meningkatkan kualitas hidup menuju kesejahteraan.

Menurut definisi WBCSD (2002) CSR merupakan komitmen untuk memberikan kontribusi kepada pembangunan berkelanjutan (Sustainable Development) dan bertujuan untuk meningkatkan kualitas hidup masyarakat. CSR juga memiliki 
hubungan yang erat dalam kerangka tujuan meningkatkan reputasi perusahaan dalam konteks pembangunan berkelanjutan (Sustainable development) (Silveira \& Petrini, 2018). Hudayana (2011) berpendapat kearifan lokal merupakan nilai-nilai luhur yang mempunyai tujuan untuk memperbaiki kualitas hidup manusia. Kearifan lokal mengandung prinsip nilai moral universal seperti keadilan, perlindungan kepada kaum lemah atau minoritas, memperbaiki kualitas lingkungan, energi yang dapat diperbaharui sehingga dapat mewujudkan kesejahteraan manusia. Meliono (2011) menambahkan kearifan lokal mencakup ide-ide, kegiatan dan aktivitas manusia serta artefak sebagai wujud keberagaman suku-suku bangsa maupun etnik. Kearifan lokal merupakan kumpulan budaya-budaya etnis. Kearifan lokal dapat berwujud ide, maupun aktivitas masyarakat lokal.

Menurut Kongprasertamorn (2007:2), kearifan lokal adalah pengetahuan yang digunakan sebagai panduan hidup termasuk membina hubungan dengan semua individu yang hidup di lingkungan sekeliling. Menurutnya, terdapat 3 (tiga) aspek kearifan lokal: pertama, kearifan lokal melibatkan pengetahuan-pengetahuan yang mengajarkan etika dan moral; kedua, kearifan lokal mengajarkan manusia untuk mencintai alam, bukan untuk memusnahkannya. Ketiga, kearifan lokal adalah warisan generasi terdahulu. Adapun Mungmachon (2012) berpendapat, kearifan lokal merupakan cara untuk warga menjaga lingkungan.

Salah satu kearifan lokal yang menonjol di Bali adalah Tri Hita Karana. Menurut
Wiana (2007) Tri Hita Karana (THK) merupakan panduan untuk mewujudkan sikap hidup yang seimbang. Percaya dan berbakti kepada Tuhan, serta mengabdikan diri demi kesejahteraan hidup masyarakat dan memelihara kesejahteraan alam sekitar. Pitana (2010) mengatakan THK memberikan panduan (guidance) masyarakat Hindu Bali untuk hidup selaras dengan lingkungan dan mempertahankan kebudayaan mereka.

THK memberikan bimbingan untuk berkelakuan yang baik yaitu kepada sesama manusia (Pawongan), alam sekitar (Palemahan), dan Tuhan Yang Maha Esa (Parahyangan) yang bertujuan agar manusia bisa meraih kesejahteraan dalam kehidupan (Siswanto et. al, 2014).

Sedangkan pada pelaksanaan CSR, faktor-faktor sosial budaya, keadaan setempat, politik, ekonomi mempengaruhi pelaksanaan CSR di berbagai negara. Di Thailand, masyarakat lokal memainkan peranan yang penting dalam sikap sosial dan politik. Aktivitas CSR meliputi program dalam pembangunan baik ekonomi, pendidikan, kesehatan masyarakat, lingkungan, persamaan gender, Hak Asasi Manusia (HAM) (Pimpa et.al, 2014). Perusahaan juga perlu melibatkan ide-ide masyarakat setempat mulai dari proses perencanaan hingga berakhirnya program CSR (Aoun, 2007:8). Sedangkan Bayoud (2013:2) mengatakan, di Libya, CSR dipengaruhi kondisi sosial, politik, agama, dan budaya masyarakat Libya, dimana agama Islam sangat mempengaruhi kehidupan masyarakat.

Menurut Alam, Hoque \& Hosen (2010) di Bangladesh, CSR disesuaikan dengan 
masyarakat setempat. Di negara-negara Asia dan Afrika, CSR berakar dari budaya lokal yang ada dan mendorong CSR sesuai dengan budaya lokal. Kayuni dan Tambulasi (2012) menegaskan konsep CSR di Malawi dilakukan berdasarkan konsep kearifan lokal Afrika yaitu Ubuntu. CSR dilaksanakan dengan pemahaman bahwa perusahaan dan masyarakat terkait satu dengan yang lain (interdependensi). Amponsah-Tawiah \& Dartney-Baah (2011) menyatakan, CSR di Afrika dan negara-negara Barat dipengaruhi budaya dan tradisi masingmasing negara. Khan dan Beddewella (2008) menyatakan, keunikan budaya di Sri Lanka dipengaruhi ajaran agama Buddha antara lain melakukan hal yang baik kepada orang lain. Ajaran ini mempengaruhi cara berpikir para manajer perusahaan dan mempengaruhi pelaksanaan CSR di Sri Lanka.

Fukukawa dan Teramoto (2009) mengatakan, konsep CSR telah dikenal lama dalam tradisi masyarakat Jepang, sebelum lahirnya konsep CSR di negara-negara barat. Masyarakat Jepang terkenal memiliki prinsip kebijakan perusahaan (keiei rinen atau hoshin). Perusahaan di Jepang memberikan sumbangan kepada masyarakat lokal dari aktivitas bisnis yang mereka lakukan, biasa disebut sebagai mono zukuri (berbuat sesuatu). Di China, konsep CSR dipengaruhi nilai-nilai Confucian. Mendorong perusahaan melaksanakan CSR sesuai tradisi tersebut (Yin dan Zhang, 2012).

Chamhuri dan Haslina (2008), CSR di Malaysia dipengaruhi kebijakan, strategi, program, dan komitmen perusahaan terhadap keadaan sosial dan lingkungannya. Abdulrazak dan Fauziah (2014) menegaskan CSR di Malaysia juga dipengaruhi oleh norma, adat, dan nilai-nilai yang dianut masyarakat. Pelaksanaan CSR di Malaysia tidak dapat mengacu sepenuhnya pada pedoman atau prinsip-prinsip CSR yang berlaku di negara-negara Barat. Bilowol dan Doan Mai (2015) menjelaskan, di Vietnam, ajaran Confucian memengaruhi penerapan CSR. Confucian mengajarkan "perdamaian, belajar, dan berkembang bersama, antara warga dan perusahaan".

Di Indonesia, konsep CSR sangat erat dengan aspek sosiologis, dimana hubungan yang terjadi diantara perusahaan dan komunitas lokal. Ketika perusahaan mengeksploitasi sumber daya alam dan mineral, maka masyarakat lokal sebagai pemangku kepentingan (primary stakeholders), bahkan sebagai "pemilik" daripada sumber daya yang dieksploitasi (Prayogo, 2013:61). Di Indonesia perusahaan maupun pelaku usaha perlu memperhatikan bahwa CSR bukan hanya sekadar kewajiban sosial namun perlu memuat prinsip-prinsip keadilan sosial dan berupaya meningkatkan kesejahteraan terhadap komunitas setempat yang pada akhirnya akan meningkatkan image positif dan dukungan sosial masyarakat terhadap perusahaan.

Tri Hita Karana merupakan kearifan lokal Bali yang menekankan bahwa hubungan dengan Tuhan, manusia dan alam memiliki kaitan satu dengan yang lain. Keharmonisan terjadi apabila ketiga hubungan tersebut dijalankan secara seimbang. Melalui pendekatan kearifan lokal THK, perusahaan Aqua Danone Bali dapat menyesuaikan diri dengan masyarakat setempat melalui programprogram CSR mereka. Berdasarkan kearifan lokal Tri Hita Karana, program CSR Aqua 
Danone Bali disesuaikan dengan kebutuhan masyarakat setempat sehingga dapat diterima oleh masyarakat lokal sebagai penerima manfaat program CSR. Salah satu program CSR Aqua Danone Bali adalah WASH (Water, Access, Hygiene, and Sanitation) yang meliputi program akses air bersih dan kampanye STBM yang berjalan melalui pendekatan Tri Hita Karana yaitu mengintegrasikan peribadatan, gotong royong dan pemeliharaan mata air dalam program WASH Aqua Danone Bali. Program WASH di Banjar Bukian Kiadan Bali berhasil membawa kedua dusun tersebut berstatus Open Defecation Free $(O D F)$, masyarakat tidak lagi buang air besar sembarangan (BABS) pada 17 Januari 2014.

\section{Metode Penelitian}

Penelitian ini menggunakan metode pendekatan kualitatif. Menurut Creswell (2009: 33) metode pendekatan kualitatif merupakan penelitian dengan memahami individu atau kumpulan dalam masalah sosial. Menurut Bryman (2012):

"Qualitative research is a research strategy that usually emphasizes words rather than quantifications in the collection and analysis of data. As research strategy it is broadly inductivist, constructionists, and interpretative. Qualitative research has become an increasingly popular approach to social research."

Bentuk penelitian ini menggunakan pendekatan studi kasus. Idrus (2009: 57) memaparkan bahwa studi kasus merupakan penelitian rinci atas peristiwa tertentu. Menurut Idrus (2009:57) studi kasus adalah penelitian intensif tentang seorang individu. Namun terkadang dapat juga digunakan untuk menyelidiki unit sosial yang kecil, seperti keluarga, sekolah, dan kelompokkelompok "geng" anak muda.
Data penelitian dikumpulkan melalui dua cara, pertama adalah wawancara mendalam dengan CSR Manager (R1), koordinator program WASH (R2), pengurus LSM (R3), tokoh masyarakat setempat (R4 orang) dan masyarakat lokal penerima manfaat CSR (R5 dan R6). Data sekunder diperoleh dari berbagai sumber dokumen antara lain Laporan CSR Aqua Danone Bali, berita-berita surat kabar mengenai CSR dan website perusahaan. Data dianalisis dengan analisis interaktif. Model ini terdiri dari tiga komponen analisis yaitu: reduksi data, sajian data, dan penarikan simpulan (Miles dan Huberman, 2014).

\section{Hasil Penelitian dan Pembahasan}

\section{CSR berdasarkan Kearifan Lokal (Local Wisdom) "Tri Hita Karana"}

Pengembangan program Aqua Danone berdasarkan pada komitmen perusahaan. Komitmen tersebut adalah cara untuk melakukan bisnis yang tidak hanya mengkhawatirkan tentang kinerja ekonomi perusahaan tetapi juga pada isu-isu sosial (sukses ekonomi dan kemajuan sosial). Gagasan ini sesuai dengan prinsip-prinsip pendiri Aqua, Tirto Utomo, bahwa bisnis harus seiring dengan kontribusi perusahaan kepada masyarakat. Pendiri Danone Antoni Ribound mengatakan bahwa batas terdepan dari perusahaan tidak berhenti di depan gerbang pabrik dan pintu kantor. Komitmen ini dituangkan ke dalam Payung AQUA Lestari yang dikembangkan semenjak tahun 2006. Inisiatif CSR di Danone dibawah payung Aqua Lestari terdiri dari 4 (empat) pilar; (1) perlindungan sumber daya air; (2) praktik perusahaan yang ramah lingkungan, 
(3) pengelolaan distribusi produk, dan (4) pelibatan dan pemberdayaan masyarakat.

Pendekatan yang dilakukan oleh Aqua Danone Bali dalam melaksanakan CSR adalah melalui kearifan lokal (local wisdom). Bali dikenal sebagai masyarakat yang memegang teguh adat-istiadatnya. Salah satu kearifan lokal yang dipegang teguh oleh masyarakat Bali ialah Tri Hita Karana (THK). Inti ajaran THK adalah penekanan kepada tiga hubungan manusia dalam kehidupan di dunia, yaitu Tuhan, manusia dan alam. Menurut responden R1 (manajer CSR) dalam petikan wawancara berikut:

"Filsafat THK ini menjadi panduan CSR. Filsafat ini mengajarkan bahwa ketiga aspek yaitu Tuhan, manusia dan alam adalah tidak dapat dipisah-pisahkan. Atas dasar inilah CSR dikembangkan dengan konsep konservasi terpadu. Konservasi terpadu dalam CSR ini artinya bukan hanya konservasi alam tetapi juga meningkatkan kualitas kehidupan warga khususnya aspek kesehatan dan sanitasi. Bagi masyarakat Hindu Bali, memelihara alam dan lingkungan merupakan wujud kecintaan kepada Tuhan,"

Bagi masyarakat Hindu Bali, sungai dianggap sangat penting. Sungai digunakan untuk ibadah Umat Hindu sehingga kesucian sungai harus dijaga. Hulu sungai ibarat kepala, harus suci, bersih dari kotoran, dan mesti dihormati. Sedangkan dilihat dari fungsi sosial, sungai dipergunakan untuk memenuhi kebutuhan air minum, irigasi pertanian, serta pariwisata. Agar sungai memiliki kegunaan bagi Umat Hindu, harus dipelihara dan dirawat.

Aqua Danone-Bali menerapkan kearifan lokal Tri Hita Karana sebagai panduan CSR di sepanjang Daerah Aliran Sungai (DAS) Ayung, Bali. DAS Ayung mempunyai arti penting bagi kehidupan masyarakat. Sungai Ayung digunakan untuk ritual keagamaan berupa penyucian dan pemujaan kepada Dewa Penguasa Lautan, yakni Bhatara Baruna. Ritual tersebut dapat dilihat pada upacara Melis atau Melasti. Pada upacara Melasti ini, masyarakat memohon "Tirta Segara", yakni air suci dari mata air yang mengalir dari tepi sungai, yang disebut Beji. Air suci ini untuk melengkapi ritual Nyepi dan Odalan (Patirtan). Selain itu, aliran Sungai Ayung digunakan pula untuk ritual Malukat (rawatan pribadi) yang dilakukan di Campuhan (lokasi pertemuan dua atau lebih anak sungai) untuk keperluan pengobatan (Suarja et.al, 2014).

Sepanjang aliran Sungai Ayung terdapat banyak lokasi yang bernilai suci. Lokasilokasi tersebut digunakan masyarakat setempat untuk melakukan ritual keagamaan. Masyarakat Bali mengenal ajaran "Tri Kang Singangguh Manik Sarwo Molih". Artinya tiga permata yang paling utama bagi kehidupan manusia, yaitu air, hutan dan ilmu pengetahuan. Ketiga "permata" ini harus dijaga dengan baik sehingga memberikan manfaat bagi kehidupan manusia (Suarja et.al, 2014) Pendekatan yang terpadu dimulai dari tingkat perencanaan program, perumusan kebijakan, pelaksanaan hingga evaluasi program CSR. Menurut responden R1 (manager CSR) dalam wawancara mendalam:

"Melalui CSR, tiga nilai Tri Hita Karana (THK) dilaksanakan melalui hubungan dengan Tuhan (parahyangan), keseimbangan hubungan antara manusia (pawongan) maupun hubungan dengan alam (palemahan). Prinsip untuk menjalankannya adalah seimbang dan selaras (harmoni). Hidup manusia akan bahagia dan tentram jika keseimbangan dapat dicapai dan dijauhkan dari perilaku buruk." 
Tabel 1.1 Aktualisasi Nilai Tri Hita Karana dalam Program CSR Aqua Danone Bali

\begin{tabular}{ll}
\hline Aspek Tri Hita Karana & Aktualisasi \\
\hline Membina hubungan baik & Melaksanakan upacara persembahan untuk setiap tahap kegiatan CSR seper- \\
dengan Tuhan (Parahyangan) & $\begin{array}{l}\text { ti upacara agama untuk memulai pembangunan sarana air bersih (Ngeruak) } \\
\text { di lokasi sumber air. Tujuannya memohon doa restu dan anugerah dari Tuhan } \\
\text { dan pencarian hari baik untuk memulai suatu kegiatan baik }\end{array}$ \\
Membina hubungan baik antar & $\begin{array}{l}\text { Pelaksanaan gotong-royong, bekerjasama dengan berbagai berbagai pihak } \\
\text { dalam aktivitas CSR dalam pembangunan jamban dan menggunakan }\end{array}$ \\
manusia (Pawongan) & forum-forum setempat seperti sangkep untuk mendiskusikan masalah, pen- \\
& genalan program, pelaksanaan dan evaluasi program STBM (Sanitasi Total \\
& Berbasis Masyarakat) \\
Membina hubungan baik & Kegiatan CSR yang memiliki visi ke arah pemeliharaan lingkungan seperti \\
dengan alam (Palemahan) & pemeliharaan sumber dan mata air \\
\hline
\end{tabular}

Sumber: data primer yang diolah

CSR Aqua Danone Bali mengembangkan program pembangunan masyarakat (Community Development). Salah satunya dengan memelihara sumber mata air di hulu, tengah, dan hilir Sungai Ayung. Konsep THK diwujudkan melalui program-program konservasi terpadu. Mengintegrasikan tiga elemen, Tuhan, manusia dan alam dalam program CSR.

Dari tabel 1.1 tersebut dapat dikatakan bahwa ketiga aspek dalam THK dilibatkan dalam program CSR Aqua Danone Bali. Aspek hubungan dengan Tuhan (Parahyangan) diwujudkan melalui kegiatan upacara persembahan di setiap awal dan akhir kegiatan, membina hubungan baik dengan orang lain (Pawongan) dilaksanakan dalam kegiatan gotong royong dan hubungan baik dengan alam (Palemahan) dilaksanakan melalui pemeliharaan memelihara sumber air dan lingkungan alam.

\section{Partisipasi masyarakat dalam CSR melalui sumber-sumber lokal}

Program Water Access Sanitation and Hygiene (WASH) yang dilaksanakan oleh Aqua Danone Bali di Banjar Bukian dan
Kiadan, wilayah Badung-Bali meliputi; (1) penyediaan air bersih bagi masyarakat melalui teknologi pompa hidrolik dan kincir air, (2) pelaksanaan kampanye Sanitasi STBM, dan (3) pengelolaan air bersih oleh Kelompok Pengelola Sarana Air Bersih (KPSAB).

Aqua Danone Bali menerapkan strategi mengelola sumber daya air secara terpadu melalui program WASH. Program ini dijalankan di area permukiman penduduk yang berada di Daerah Aliran Sungai (DAS) dimana Aqua Danone Bali beroperasi. Juga diterapkan di daerah yang akses terhadap air bersih rendah. Satu di antaranya, diterapkan di Desa Belok Sidan, Kecamatan Petang, Kabupaten Badung.

Di wilayah Jempanang, terdapat 50 Kepala Keluarga (KK) yang belum bisa mengakses air bersih, khususnya warga yang tinggal di Tempek Pucak Sari. Wilayah tersebut terdapat sumber mata air bersih, namun tidak dapat diakses warga karena keterbatasan peralatan dan dana. Atas dasar hal tersebut, Aqua Danone Bali bekerjasama dengan masyarakat mengembangkan program penyediaan dan akses air bersih. 
Saat diwawancarai, R1 (CSR Manager) Aqua Danone Bali mengatakan:

"Air bersih penting untuk masyarakat. WASH digelar untuk membangun fasilitas air bersih. Berupa teknologi kincir air dan pompa hidrolik. Penggunaan teknologi tersebut sesuai dengan keadaan wilayah setempat dan supply air sungai yang sesuai."

Menurut responden R1 (CSR Manager) kegiatan WASH juga meliputi kegiatan mengajak warga mempraktikkan Perilaku Hidup Bersih dan Sehat (PHBS). Seperti dikatakan responden R1 (CSR Manager) saat wawancara:

"Salah satu perilaku buruk warga adalah kebiasaan Buang Air Besar Sembarangan (BABS) di kebun atau halaman yang terbuka. Praktik itu menyebabkan tercemarnya sumber air oleh bakteri $e$-coli dan tersebarnya penyakit diare."

Guna mencapai tujuan agar warga menerapkan PHBS, Aqua Danone Bali melakukan beberapa langkah strategis. Pertama, mengenalkan program WASH secara informal kepada masyarakat. Dengan cara melakukan kunjungan ke rumah para prajuru (Kelian Banjar Adat, Kelian Banjar Dinas, dan Kelian Subak). Juga digelar pertemuan formal dengan warga (sangkepan). Kedua, pengenalan program melibatkan tokoh-tokoh masyarakat lokal. Dimulai dengan pendekatan kepada para prajuru Banjar Bukian untuk merundingkan tempat, fasilitas yang akan dibangun serta mekanisme pembangunan pompa hidrolik.

Aqua Danone Bali juga menggelar kampanye STBM (Sanitasi Total Berbasis Masyarakat) yang bertujuan mengubah perilaku buruk masyarakat di DAS Ayung agar tidak mempengaruhi kualitas air Sungai Ayung. Langkah yang dianbil berupa pendekatan
Sanitasi Total Berbasis Masyarakat (STBM) yang terdiri dari lima pilar.

Lima pilar tersebut berupa stop buang air besar sembarangan (BABS), mencuci tangan menggunakan sabun, mengelola air minum rumah tangga, mengelola sampah dan limbah rumah tangga. Pengenalan program pada awalnya dilakukan kepada pemimpin banjar. Guna mempercepat proses penyadaran masyarakat akan hidup sehat, maka digelar kerjasama dengan berbagai pihak. Ada pula pembentukan pelatih sanitasi sebanyak 20 orang, yang kemudian mengikuti latihan Training of Trainer (TOT) dibantu Water Sanitation Program (WSP). Keduapuluh orang ini dilatih melakukan triggering (pemicuan), yakni memicu rasa malu, jijik, dan takut dosa jika melakukan BABS.

Menurut responden R3 (anggota LSM), warga melakukan BABS karena tidak tersedianya persediaan air yang mencukupi. Mereka harus berjalan kaki cukup jauh untuk mendapatkan air. Sehingga diperlukan langkah agar warga bisa mengakses air dengan mudah agar kebiasaan BABS terkikis. Program WASH, selain penyediaan air bersih, juga mendidik warga melakukan Perilaku Hidup Bersih dan Sehat (PHBS). Termasuk menerapkan program STBM (Sanitasi Total Berdasarkan Masyarakat), terutama untuk warga yang belum punya jamban yang bersih.

Langkah penyadaran stop BABS dilakukan dengan cara gotong royong. Setiap warga diharapkan saling mengingatkan jika masih ada yang melakukan Buang Air Besar Sembarangan (BABS). Denda dijatuhkan jika ada warga yang masih melakukan praktik 
BABS. Seperti diungkapkan Responden R4 (Ketua Banjar) dalam wawancara mendalam:

"Pelarangan BABS diperkuat melalui pararem (aturan adat). Setiap rumah harus ada jamban sehat dan bersih. Yang melanggar aturan dikenakan denda Rp 5.000 serta periuk nasi diambil. Sanksi sosialnya akan lebih berat, yakni rasa malu."

Program WASH lainnya adalah pembentukan Kelompok Pengelola Sarana Air Bersih (KPSAB). Kelompok ini dibentuk untuk mengelola sarana air bersih. Tugas kelompok adalah mengelola dan merawat sarana air bersih, serta mendistribusikan air bersih kepada penduduk yang memerlukan.

Sedangkan responden R5 dan R6 (masyarakat lokal) mengatakan, program WASH sangat membantu masyarakat. Berpuluh-puluh tahun sebelumnya, warga harus mengambil air dari dasar jurang. Dengan adanya program WASH, warga mendapat kepastian penyediaan air bersih. Perilaku Hidup Bersih dan Sehat (PHBS) juga meningkat. Masyarakat lokal juga mendapat manfaat dari program WASH berupa penyediaan jamban bersih di rumahrumah. Sehingga kualitas kesehatan warga semakin membaik.

Masyarakat setempat pun antusias menyambut program WASH. Mereka rela bergotong royong membangun jamban untuk warga yang belum memiliki. Warga satu per satu meninggalkan kebiasaan BABS. Mereka kini melakukan buang air besar (BAB) di jamban bersih yang mereka bangun.

Kebiasaan buang air besar sembarangan (BABS) berkurang dan mulai bisa dihilangkan. Kesadaran penduduk Banjar Bukian dan Kiadan terhadap Perilaku Hidup Bersih dan Sehat (PHBS) semakin meningkat. Pada tahun
2015, di Banjar Jempanang, sebanyak 672 penduduk (168 kepala keluarga) telah memiliki jamban dan tidak melakukan BABS. Sebanyak 47 kepala keluarga masih menggunakan jamban joint system. Hanya tinggal tiga 3 kepala keluarga yang masih melakukan BABS dan tidak memiliki jamban.

Sedangkan di Banjar Bukian, sebanyak 798 penduduk (198 kepala keluarga) sudah punya jamban. Masih ada satu kepala keluarga yang melakukan BABS. Di Banjar Tinggan, sebanyak 484 penduduk (121 KK) memiliki jamban dan 52 KK memiliki jamban sehat dengan cara joint system. Terdapat satu keluarga memiliki jamban yang rusak dan empat kepala keluarga dalam proses membangun jamban (Laporan Akhir Program Ayung Lestari, 2015)

Fokus dari program CSR Aqua Danone Bali adalah mengkreasikan dan mempromosikan perilaku hidup bersih dan sehat kepada masyarakat. Sekaligus meningkatkan kualitas kehidupan masyarakat melalui pendekatan Tri Hita Karana. Melibatkan unsur peribadatan kepada Tuhan, hubungan dengan manusia, dan alam. Hal ini sejalan dengan definisi CSR menurut WBSCD (2002) yang mengatakan CSR merupakan komitmen untuk memberikan kontribusi kepada pembangunan berkelanjutan (Sustainable Development) dan bertujuan untuk meningkatkan kualitas hidup masyarakat.

CSR yang dilaksanakan oleh Aqua Danone Bali tidak diwujudkan dalam bentuk pemberian donasi (bantuan keuangan) namun berupa program-program pemberdayaan masyarakat. CSR yang dilaksanakan oleh 
Aqua Danone Bali berada pada wilayah etika bisnis yang melampui kewajiban ekonomi dan hukum.

Berbagai keberhasilan telah dicapai oleh masyarakat setempat melalui program WASH, antara lain; (1) masyarakat Bukian dan Jempanang telah mengakses air bersih langsung di rumah atau dekat dengan rumah masing-masing, dan (2) masyarakat setempat memiliki kesadaran terhadap kebersihan dan sanitasi lingkungan, (3) meninggalkan praktik Buang Air Besar Sembarangan (BABS) dan mampu untuk menggunakan dan memanfaatkan jamban. Keberhasilan dan manfaat program WASH yang diperoleh oleh masyarakat di Banjar Bukian dan Kiadan ini dapat diteruskan oleh warga masyarakat dan dapat menjadi contoh oleh masyarakat lainnya.

Peran pemimpin lokal seperti Kelian Banjar (pemimpin banjar) dalam masyarakat berpengaruh besar terhadap keberhasilan program. Tokoh masyarakat lokal terus menerus menyosialisasikan program WASH kepada masyarakat melalui forum-forum adat maupun dalam pertemuan-pertemuan informal sehari-hari dengan masyarakat. Hal ini diperkuat dengan aturan adat berupa sanksi sosial yang diberikan kepada masyarakat yang tidak mau melakukan praktik Perilaku Hidup Bersih dan Sehat (PHBS). Salah satunya ialah pengenaan denda sebanyak Rp 5000,- dan juga diambilnya periuk nasi oleh penduduk setempat terhadap kalangan masyarakat yang tidak menyepakati aturan bersama.

Program CSR yang dilaksanakan oleh Aqua Danone Bali direncanakan, dilak- sanakan dan dievaluasi oleh masyarakat melalui pemanfaatan sumber-sumber lokal yang telah ada dalam masyarakat antara lain melalui pararem (aturan adat) yang melarang penduduk untuk melakukan BABS (Buang Air Besar Sembarangan). Aturan adat ini dibuat dan dilaksanakan sendiri oleh masyarakat sekaligus mereka yang menerapkan sanksi sosialnya.

\section{Simpulan}

CSR yang dilaksanakan oleh Aqua Danone Bali memiliki perspektif Sustainable Development sesuai dengan kerangka WBCSD (2002) yang bertujuan untuk meningkatkan kualitas kehidupan masyarakat. Program CSR Aqua Bali berdasarkan kearifan lokal Tri Hita Karana (THK) yang memadukan unsur peribadatan dengan Tuhan (Parahyangan,) hubungan dengan manusia (Pawongan) dan hubungan dengan alam (Palemahan) melalui kegiatan konservasi terpadu dalam bentuk program WASH (Water Access Sanitation and Hygiene).

Sungai sebagai sumber mata air memiliki arti penting dari aspek religi maupun fungsi sosial bagi masyarakat Bali. Kebersihan dan kesucian sungai harus dijaga dan dirawat. Melalui kegiatan CSR dengan pendekatan Tri Hita Karana (THK), masyarakat di sepanjang aliran Sungai Ayung melaksanakan program konservasi alam terpadu yang menyatukan elemen peribadatan, manusia dan alam. Pada aspek Parahyangan (hubungan dengan Tuhan), mereka melakukan upacara persembahan untuk setiap tahap kegiatan. Antara lain, melakukan upacara untuk memulai 
pembangunan sarana air bersih (Ngeruak) di lokasi sumber air yang tujuannya untuk memohon doa restu dan anugerah dari Tuhan dan pencarian hari baik untuk memulai suatu kegiatan yang baik.

Pada aspek hubungan dengan manusia (Pawongan), masyarakat melakukan kegiatan gotong royong dalam meningkatkan kesadaran masyarakat terhadap dampak buruk BABS terhadap individu dan lingkungan. Adapun aspek hubungan dengan alam (Palemahan) diwujudkan dalam bentuk kegiatan yang bertujuan untuk merawat lingkungan dan alam termasuk di dalamnya sumber air termasuk mata air dan sungai.

Keberhasilan program WASH juga didukung dengan adanya pemanfaatan sumber-sumber lokal, termasuk dilaksanakan melalui aturan adat yang terdapat dalam masyarakat seperti pararem (aturan adat) yang melarang praktik buang air besar sembarangan (BABS) serta mewajibkan seluruh rumah penduduk membangun jamban sehat dan pemanfaatan forum lokal seperti sangkepan (rapat rutin banjar) sebagai mekanisme kontrol sosial termasuk penegakan aturan. Dalam program WASH yang dilaksanakan oleh Aqua Danone Bali, partisipasi masyarakat serta tokoh-tokoh setempat setempat menjadi salah satu bagian penting dalam pencapaian tujuan CSR.

Dalam melaksanakan program CSR berdasarkan kearifan lokal, maka perusahaan perlu memahami kebutuhan masyarakat dari perspektif masyarakat setempat. Komunikasi dua arah (two ways communication) yang dijalin antara perusahaan dan masyarakat lokal sangat penting dan membangun hubungan dengan tokoh-tokoh masyarakat setempat. Dalam CSR yang dilaksanakan oleh Aqua Danone Bali, partisipasi masyarakat setempat (community engagement) menjadi salah satu bagian penting dalam pencapaian tujuan. Oleh karena itu, masyarakat setempat perlu dilibatkan secara aktif dalam tiap proses yaitu identifikasi masalah; proses perencanaan yaitu masyarakat dilibatkan dalam penyusunan rencana dan strategi dengan berdasar pada hasil identifikasi; pelaksanaan proyek CSR; evaluasi dan mitigasi serta monitoring bertahap yang dilakukan agar proses CSR dapat berkelanjutan. Masyarakat juga perlu kritis untuk memberikan masukanmasukan kepada program CSR yang telah dilaksanakan oleh Aqua Danone Bali.

\section{Daftar Pustaka}

Abdulrazak, S.R.,\& Fauziah Ahmad. (2014). The Basis for CSR in Malay. Global Business and Management: An International Journal, 6(3), 210-218.

Alam, S. M Shafiul., Hoque, Shah Md. Safiul.,\& Hosen, Md. Zakir. (2010). Corporate Social Responsibility (CSR) of MNCs in Bangladesh: A Case Study on GrameenPhone Ltd. Journal of Potuakhali University of Science and Technology, Forthcoming, 2, 112-127

Amponsah-Tawiah.,\& Dartey-Baah, K. (2011). CSR in Ghana. International Journal of Business and Social Science, 2(17), 107-112.

Argandona, A., \& Hoivik, H.W. (2009). CSR: One Size Does Not Fit All, Collecting Evidence from Europe. IESE Business School, University of Navarra Spain, 1-19 
Aoun, G. (2007). CSR practices in MNC facing local environment: case of the Middle East. Paper presented in ITESO (Guadalajara, Mexico) at the IAJBS 13th International Forum in June 2007.

Bayoud N.S. (2013). How the Libyan Context Can Shape Corporate Social Responsibility dislosure in Libya. Journal of Accounting and Marketing, 2(3), 1-5

Bilowol, J., \& Doan, M.A. (2015). Multinational Corporation's Role in developing Vietnam's Public Relations industry through CSR. Public Relations Review, 41, 825-832.

Bryman, A. (2012). Social Research Methods. Fourth Edition. New York, NY: Oxford University Press

Chamhuri Shiwar \& Siti Haslina Md Harizan. (2008). A Study on CSR Practices Amongst Business Organizations in Malaysia, Environment and Development (LESTARI), Universiti Kebangsaan Bangi, Selangor, 1-16

Chapple, W., \& Moon, J. (2005). CSR in Asia: A seven-country of CSR Web site reporting. Business Society, 44, 415-430

Creswell, J.W. (2009). Research Design, Qualitative, Quantitative and Mixed Methods Approaches. Thousand Oaks, California USA:Sage Publications.

Cruz, LB,. \& Boehe, D.M. (2010). How Do Leading Retail MNC's leverage CSR Globally? Insights From Brazil. Journal Business Ethics, 91, 243-263

Daft, R.L. (2016). Management (12 ${ }^{\text {th }}$ Ed). Publisher Cengage Learning

Fukukawa, K., \& Teramoto, Y. (2009). Understanding Japanese CSR: the Reflections of Managers in the Field of Global Operations. Journal of Business Ethics, 85, 133-146

Frynas, J.G. (2009). Corporate Social Responsibility in The Oil and Gas
Sector. Journal of World Energy Law and Business, 2(3), 178-195

Godiwalla, Y.H. (2012). Business Ethics for Foreign Subsidiaries. Journal for Modern Accounting \& Auditing, 8(9), 1381-1391.

Hudayana, B. (2011). Konseptualisasi Pemberdayaan Masyarakat di Wilayah Industri Tambang dan Migas Berbasis pada Kearifan Lokal. Jurnal IRE Vol IV/ No 7/2011, 2-33

Idrus, M. (2009). Metode Penelitian Ilmu Sosial: Pendekatan Kualitatif dan Kuantitatif. 2th Ed. Jakarta: Erlangga

Kayuni, H.M ., \& Tambulasi, R.I.(2012). Ubuntu and Corporate Social Responsibility: the Case of Selected Malawian Organization. African Journal of Economic and Management Studies, 3(1), 64-76

Khan, F., \& Beddewella, E. (2008). CSR Practices: a Comparative Study of Local and MNC companies in Sri Lanka. Sri Lankan Jounal of Management, 13(3), 1-21

Kongprasertamon, K. (2007). Local Wisdom, Enviromental Protection and Community Development: the Clan Farmers in Tambon Bakhunsai, Petchaburi Province, Thailand. Manusya: Journal of Humanities, 10(1), 1-10

Laporan Akhir Program Ayung Lestari (2015). Denpasar: PT Tirta Investama-JANMA

Lo, S., \& Sheu, H. (2007). Is Corporate Sustainability a Value-Increasing. Corporate Governance: An International Review, 15, 345-358.

Miles and Huberman (2014). Qualitative Data Analysis: A Methods Sourcebook, $3^{\text {rd }}$ Ed, Sage Publications: Los Angeles, London, New Delhi, Singapore and Washington DC

Micheal, B. (2003). Corporate Social Responsibility in International 
Development: An Overview and Critique. Corporate Social Responsibility Environmental Management, 10(3), 115-128

Meliono, I. (2011). Understanding the Nusantara Thought and Local wisdom as an aspect of Indonesian Education. Tawarikh: International Journal for Historical Studies, 2(2)

Mungmachon, R. (2012). Knowledge and Local Wisdom: Community Treasure. International Journal of Humanities and Social Sciences. 2(13), 174-181.

Pimpa, N., Moore, T., Tenni, B., Supachalasai, S., Wayakone, S.D., Gregory, S. (2014). The Thai way of CSR: the case of mining Industry. Paper presented at the $12^{\text {th }}$ International Conference on Thai Studies, Sydney, Australia: University of Sydney.

Pitana, I.G (2010). The Hita Karana, The Local Wisdom of the Balinese in Managing Development, in R. Conrady $\&$ M. Buck (ed). Trends and Issues in Global Tourism Springer, 3, 139-150, Berlin : Verlag Heidelberg

Prayogo, D. (2013). Measuring CSR for local communities in mining, oil and gas industries, the case of Indonesia. Journal of Economics and Sustainable Development, 4(1), 59-69.

Petkeviciene, M.S (2015). CSR Reasons, Practices and Impact to Corporate Reputation. Presented at $20^{\text {th }}$ International Scientific Conference Economic and Management. Proceedia Social and Behavioral Sciences 213, 503-508

Shah, M. H., \& Chen, X. (2010). Advertising wounds, public relations cure: Corporate social responsibility perspective in China. International Journal of Business \& Social Science, 1(2), 137-153.

Silveira, L.M \& Petrini, M. (2018). Sustainable Development and CSR: a Bibliometric Analysis of International Scientific Production. Gest. Prod. Sao Carlos, 25(1), 56-67.

Siswanto, B., Djumilah Zain., Armanu Thoyib., \& Solimun. (2014). CSR Between Spirituality and Religious Values: Lessons Extracted from Hindu Perspectives in Indonesia. Journal of Management and Social Sciences, 4(9), $1-9$

Suarja, G., Suardika, P.P., Manu Drestha., Dzulfikar Ali Sauwibi., Yasa Utama \& Eka Pertiwi Sari, I.A. (2014). Giri Amertha: Pengalaman Aqua Mambal Bersama Janma Dalam Mendorong Pelestarian Hulu DAS Ayung. Denpasar, Bali: Perkumpulan Janma

Sun, William, Jim Stewart dan David Pollard. (2010). Reframing CSR: Lessons The Global Financial Crisis. Critical Studies on Corporate Responsibility. Governance and Sustainability, Vol 1, 3-19

Wiana, I.K. (2007). Beragama bukan Hanya Di Pura Agama Hindu Sebagai Tuntunan Hidup. Denpasar: Yayasan Dhrama Naradha.

Yin, J., \& Zhang, Y. (2012). Institutional Dynamics and Corporate Social Responsibility (CSR) in an Emerging Country Context: Evidence from China. Journal of Business Ethics, 111(2), $301-316$ 